\title{
APRESENTAÇÃO
}

\section{DUAS PALAVRAS}

\author{
Marco Lucchesi
}

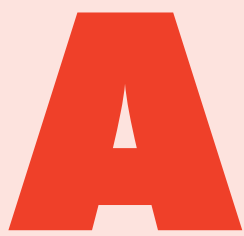

ciência e a literatura não são inimigas. Não se limitam a campos de guerra. Não se excluem como dois corpos estranhos e antagônicos. Integram uma intensa e profunda situação cultural. Leonardo da Vinci, passado meio milênio, ainda é fonte de inspiração para o diálogo entre dois mundos que se abraçam, entre dois polos que se nutrem e se inauguram. Os olhos de Mona Lisa e a projeção perspectiva, arte e ciência constituem um só gesto. Formas de chegar mais longe, mediante poéticas ousadas, que se interpenetram: tornam as fronteiras suaves, subvertem ideias fixas, propōem desenhos e gradientes.

Ciência e literatura, em diálogo, criam percursos ambiciosos, segundo uma tensão mais radial do conhecimento, vocação expansiva, com fome de mundo, olhando para todos os lados, com espanto e entusiasmo. Os textos de Lucia Santaella, Ana Maria Haddad, Márcia Fusaro, Diana Navas, Patrícia Fanaya, Júlio do Valle e Estela Guedes retomam um horizonte de ousadia e inovação. Será decerto uma forma de apressar o futuro.

Marco Lucchesi é poeta, romancista e ensaísta. É professor da Universidade Federal do Rio de Janeiro (UFRJ) e possui dezenas de livros publicados no Brasile no exterior. Atualmente éo presidente da Academia Brasileira de Letras (ABL) onde ocupa a cadeira de no. 15. 